\title{
Accommodation Project for Physically Restricted Personnel, Phase 1 Addendum: Job-Based Criteria for Nonskilled Heavy Laborers
}

\author{
Larry L. Young III, Paul B. Mossman
}

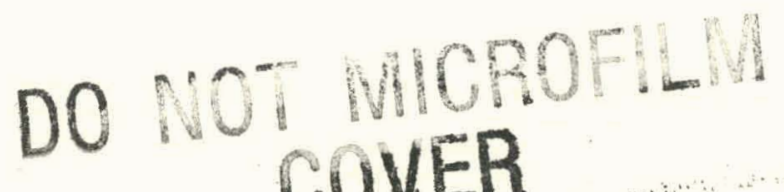

Prepared by

Sandia National Laboratories

Albuquerque, New Mexico 87185 and Livermore, California 94550

for the United States Department of Energy

under Contract DE-AC04-76DP00789

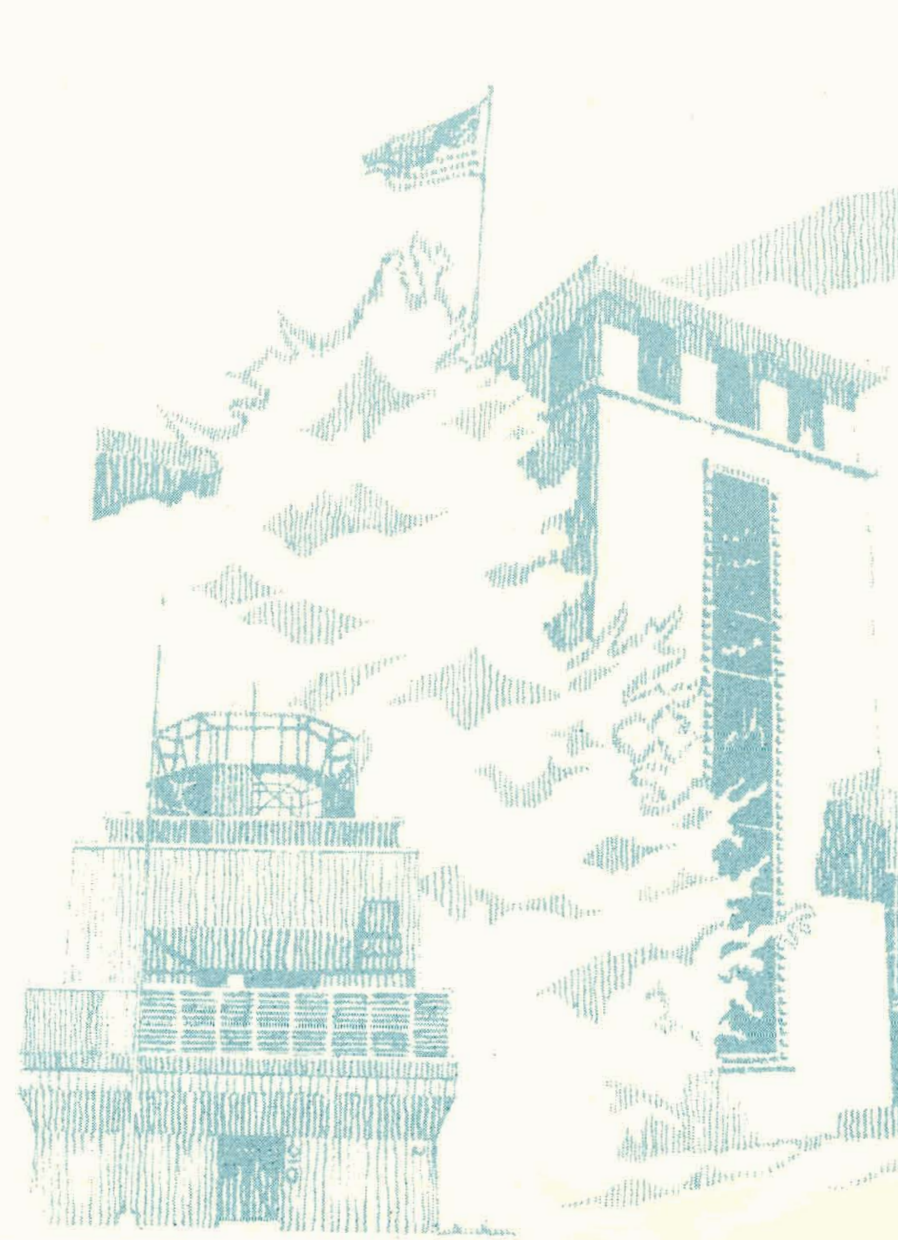




\section{DISCLAIMER}

This report was prepared as an account of work sponsored by an agency of the United States Government. Neither the United States Government nor any agency Thereof, nor any of their employees, makes any warranty, express or implied, or assumes any legal liability or responsibility for the accuracy, completeness, or usefulness of any information, apparatus, product, or process disclosed, or represents that its use would not infringe privately owned rights. Reference herein to any specific commercial product, process, or service by trade name, trademark, manufacturer, or otherwise does not necessarily constitute or imply its endorsement, recommendation, or favoring by the United States Government or any agency thereof. The views and opinions of authors expressed herein do not necessarily state or reflect those of the United States Government or any agency thereof. 


\section{DISCLAIMER}

Portions of this document may be illegible in electronic image products. Images are produced from the best available original document. 
Issued by Sandia National Laboratories, operated for the United States Department of Energy by Sandia Corporation.

NOTICE: This report was prepared as an account of work sponsored by an agency of the United States Government. Neither the United States Government nor any agency thereof, nor any of their employees, nor any of their ment nor any agency thereof, nor any of their employees, nor any of their contractors, subcontractors, or their employees, makes any warranty, express
or implied, or assumes any legal liability or responsibility for the accuracy, completeness, or usefulness of any information, apparatus, product, or process disclosed, or represents that its use would not infringe privately owned rights. Reference herein to any specific commercial product, process, or service by trade name, trademark, manufacturer, or otherwise, does not necessarily constitute or imply its endorsement, recommendation, or favoring by the United States Grovernment, any agency thereof or any of their contractors or subcontractors. The views and opinions expressed herein do not necessarily state or reflect those of the United States Government, any agency thereof or any of their contractors or subcontractors.

Printed in the United States of America Available from

National Technical Information Service

U.S. Department of Commerce

5285 Port Royal Road

Springfield, VA 2216

NTIS price codes

Printed copy: A02

Microfiche copy: A01 


\section{DISTRIBUTION:}

Dr. Fernando Madrigal Lozano

El Secretario

Facultad de Medicina

Universidad Autónoma de Chihuahua

APDO 1090

Chihuahua, Chihuahua, MEXICO

Dr. Carlos Aguilar

Av. Vicente Guerreo

No. 610

Chihuahua, Chihuahua, MEXICO

University of New Mexico

Psychology Dept

Psychology Bldg Rm 108

Albuquerque, NM 87106

Attn: M. Brecht

$\begin{array}{ll}1100 & \text { F. L. Vook } \\ 2300 & \text { J. C. King } \\ 3000 & \text { R. B. Powell } \\ 3100 & \text { H. M. Willis } \\ 3150 & \text { T. B. Heaphy } \\ 3154 & \text { A. E. Jones } \\ 3154-4 & \text { J. Hernandez } \\ 3300 & \text { P. B. Mossman (10) } \\ 3300 & \text { L. L. Young (6) } \\ 3310 & \text { W. D. Burnett } \\ 3311 & \text { D. R. Parker } \\ 3321 & \text { F. H. Johnson } \\ 3330 & \text { J. W. Ewing } \\ 3332 & \text { L. R. Clevenger }\end{array}$

3332

3400

3420

3426

3440

3441

3442

3450

3451

3500

3510

3530

3551

3551

3551

3600

7223

7223

7500

8200

8210

8212

8216

8216

8275

8400

9400

8214

3141

3151

3154-3
L. Suzuki

D. S. Tarbox (5)

K. E. Sutton

R. T. Williams

L. M. Jercinovic

J. R. Doyle

D. S. Kessel

E. C. Peterson (5)

R. P. Kelly (3)

J. R. Garcia (3)

G. Banos (2)

L. H. Pitts (2)

J. H. Kelly

J. P. Sanchez

M. H. Martinez

R. W. Hunnicutt (2)

A. D. Swain

H. E. Guttmann

W. A. Gardner

A. N. Blackwell

P. E. Brewer (3)

D. Wagner

C. A. Verity

J. E. Rhodenbaugh

P. K. Lovell

L. Gutierrez

A. W. Snyder

M. A. Pound

L. J. Erickson (5)

W. L. Garner (3)

C. H. Dalin (25)

For DOE/TIC (Unlimited Release) 
SAND82-1354

Unlimited Release

Printed August 1982

\section{Accommodation Project for Physically Restricted Personnel, Phase 1 Addendum: Job-Based Criteria for Nonskilled Heavy Laborers}

Larry L. Young III*

Paul B. Mossman, MD

Medical Director 3300

Sandia National Laboratories

Albuquerque, NM 87185

\section{Abstract}

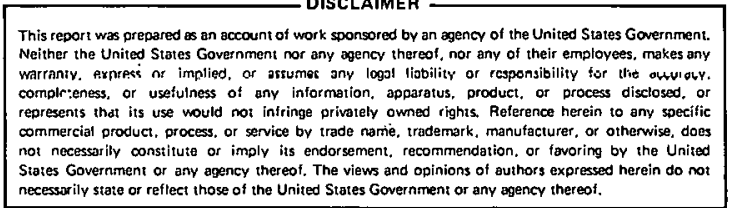

A study was conducted to determine possible accommodations for physically or medically restricted persons in the unskilled heavy labor group at Sandia National Laboratories. We conclude that only a very limited number of physically restricted persons might be accommodated under special conditions.

*On leave of absence from the Facultad de Medicina de la Universidad Autónoma de Chihuahua 


\section{PAGES 2 to 4 WERE INTENTIONALLY LEFT BLANK}




\section{Contents}

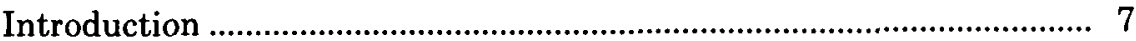

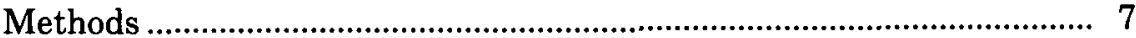

Results........................................................................................... 7

Telecon Crew...................................................................................... 7

Excavating Crew ................................................................................... 9

Cleanup Crew ……................................................................................ 10

Grounds Crew........................................................................................... 11

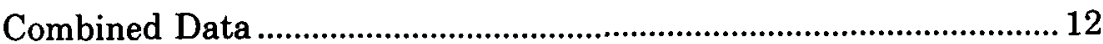

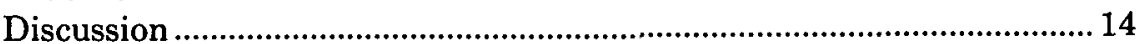

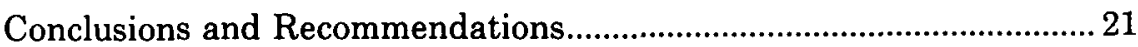

Physically Restricted/Functionally Limited Employees......................21

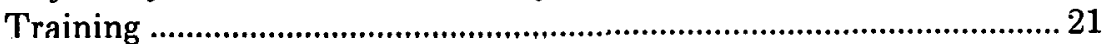

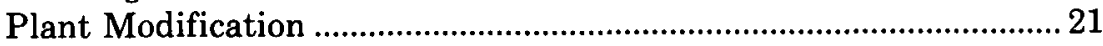

Administrative Changes.......................................................................... 22

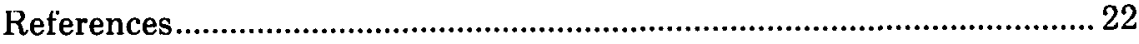

\section{Figures}

1 Laborers Lifting Heavy Object ...................................................... 18

2 Laborers Pulling/Pushing Heavy Load ......................................... 18

3 Laborers Using Jackhammer ......................................................... 19

4 Twisting of Torso ......................................................................... 19

5 Improper Lifting Technique ......................................................... 20

\section{Tables}

1 Activity/Body Position: Percentage of Occurrence Per Half-Shift for Telecon Crew

2 Activity/Body Position: Percentage of Occurrence Per Half-Shift for Excavation Crew

3 Activity/Body Position: Percentage of Occurrence Per Half-Shift for Cleanup Crew .

4 Activity/Body Position: Percentage of Occurrence Per Half-Shift for Grounds Crew ........................................................... 11

5 Aclivily/Body Position: Percentage of Occurrence Per Half-Shift for Combined Data ....................................................... 13

6 Items Most Often Lifted by Single Person on Telecon Crew ..... 14

7 Physical and Ergonomic Aspects of the Most Common Activities/Body Positions of Selected Nonskilled Heavy Laborers 


\section{Accommodation Project for Physically Restricted Personnel, Phase 1 Addendum: Job-Based Criteria for Nonskilled Heavy Laborers}

\section{Introduction}

The Medical, Safety, and Personnel Departments of Sandia National Laboratories have been involved in determining the actual task-related physical requirements of certain nonskilled labor jobs. Previous studies have already been reported on certain entry level jobs. ${ }^{1}$

Without accurate information concerning the musculoskeletal demands of specific jobs, it is difficult for the Personnel Department to judge what constitutes reasonable accommodations of physically restricted personnel. It is also difficult for our physicians to apply meaningful restrictions on individuals without a detailed analysis of the job, especially regarding the physical requirements. This was the primary reason for the initiation of the study.

This study covers the entire spectrum of physical activity and will assist in defining which physical restrictions would preclude any accommodations and those restrictions that would require only minimal accommodations on the part of line organizations.

The data obtained in this study will assist the Medical, Safety, and Personnel Departments as well as line supervision in properly placing the physically restricted individual.

\section{Methods}

A musculoskeletal stress analysis was performed un nunskilled lieavy laburers using a 15-s interobservational period survey. Each test subject was followed for one-half work shift; the activity/budy jusition was recorded every $15 \mathrm{~s}$. Only that activitiy exhibited by the worker at the end of each 15-s interval was recorded. When a combination of body positions was exhibited at observation, the predominant feature was recorded. Periods of nonproductive activity greater than $5 \mathrm{~min}$ were eliminated from the final observational data.
Prior to initiating the study, the laborers in each group were observed in order to determine the most common activity/body positions. From this preliminary observation, a list of the 30 most common activities/body positions was constructed, and these were used as the primary measurement media.

To minimize the "Hawthorn Effect" (i.e., the change in behavior due to the measurement process), the project and the analysis were explained to the section supervisor, lead personnel, and all laborers as a group and individually. Emphasis was placed on the confidentiality of each individuals' data and the author's interest in the job demands, not the efficiency of any one employee.

Analysis of the data involved the computation of the percentage of the total number of observations accounted for by each of the 30 activity/body positions for each worker, the averages, and the ranges for all laborers combined. Valid data were obtained for 27 half work shifts of the 19 nonskilled heavy laborers.

Average weights and their ranges were determined for commonly lifted items.

\section{Results}

\section{Telecon Crew}

Table 1 lists the average percentages and their ranges for each major activity/body position. The most commonly observed activity was driving/riding (average $30.13 \%$, range 13.58 to $59.11 \%$ ). The second most common position was standing $(\overline{\mathrm{x}}=14.65 \%$, range 5.78 to $27.55 \%$ ), followed closely by walking ( $\bar{x}$ $=13.76 \%$, range 3.18 to $23.20 \%$ ). Sitting takes fourth place $(\overline{\mathbf{x}}=7.43 \%$, range 0.23 to $13.30 \%$ ); pushing/ pulling wheeled objects (or objects on wheeled platforms) was fifth ( $\bar{x}=5.25 \%$, range 0 to $10.81 \%$ ). 
These were followed in order by: kneeling $(\overline{\mathrm{x}}=$ $3.87 \%, 0$ to $37.28 \%$ ), pushing/pulling nonwheeled objects $(\vec{x}=3.23 \%, 0.29$ to $6.38 \%)$, forward bending ( $\bar{x}$ $=2.67 \%, 0.62$ to $4.13 \%)$, lifting heavy objects $(\overline{\mathrm{x}}=$ $2.05 \%, 0.58$ to $3.46 \%)$, carrying light objects $(\overline{\mathrm{x}}=$ $1.71 \%, 0$ to $4.64 \%$ ), standing while working with hands $(\overline{\mathrm{x}}=1.64 \%, 0.28$ to $4.02 \%)$, carrying heavy objects ( $\overline{\mathrm{x}}=1.61 \%, 0.23$ to $2.93 \%)$, supported bending or leaning $(\overline{\mathrm{x}}=1.56 \%, 0$ to $5.26 \%)$, squatting $(\overline{\mathrm{x}}=$ $1.33 \%, 0$ to $8.38 \%$ ), lifting light objects ( $\bar{x}=1.24 \%$, 0.23 to $2.89 \%)$, lifting boxes $(\bar{x}=1.20 \%, 0$ to $4.26 \%$ ), and carrying boxes $(\bar{x}=1.07 \%, 0$ to $3.65 \%)$. The remainder of the recorded activity/body positions individually account for less than $1 \%$ of the total average number of observations, and in aggregate account for 5.68 of the total average.

\section{Table 1. Activity/Body Position: Percentage of Occurrence Per Half-Shift for Telecon Crew}

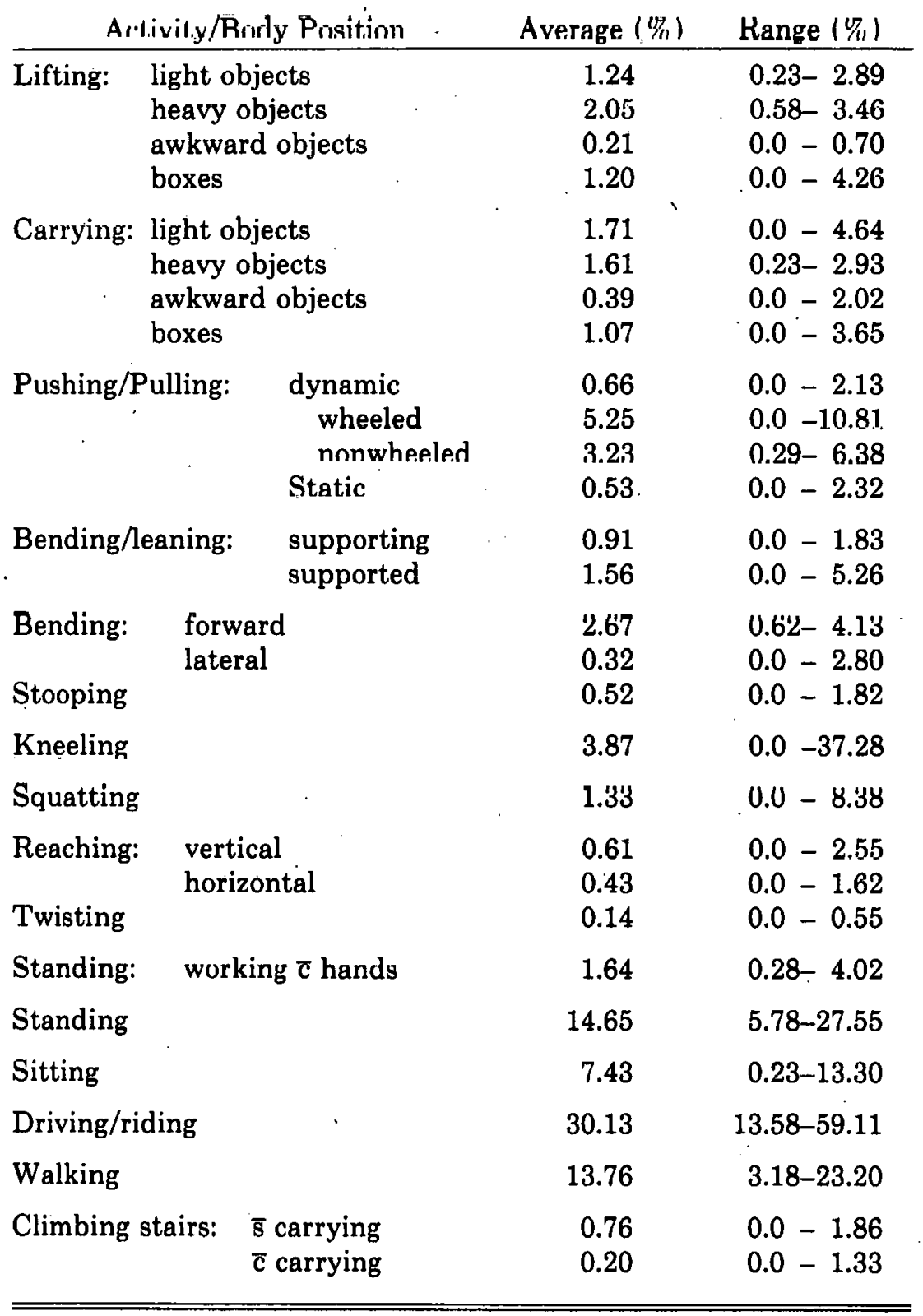




\section{Excavating Crew}

The average percentages and their ranges for each major activity/body position observed for the Excavation Crew are listed in Table 2. Driving/riding was the most common activity observed $(\overline{\mathrm{x}}=26.49 \%$, range 8.58 to $93.08 \%$ ). Standing was the second most common activity $(\overline{\mathrm{x}}=18.38 \%, 0.0$ to $36.63 \%)$ and forward bending was third ( $\overline{\mathrm{x}}=9.05 \%, 0.85$ to $21.80 \%)$. Operation of the backhoe was the fourth most common activity $(\overline{\mathrm{x}}=8.88 \%, 0.0$ to $71.07 \%)$, even though only one person was observed in this activity.

These were followed in order by: dynamic pushing/pulling ( $\overline{\mathrm{x}}=6.43 \%, 0.0$ to $24.07 \%)$, walking ( $\overline{\mathrm{x}}=$ $6.00 \%, 0.63$ to $10.90 \%)$, lifting light objects $(\overline{\mathrm{x}}=$ $4.90 \%, 0.63$ to $10.82 \%$ ), carrying light objects ( $\bar{x}=$ $3.50 \%, 0.99$ to $9.14 \%)$, lifting heavy objects $(\overline{\mathrm{x}}=$ $2.74 \%, 0.31$ to $6.76 \%$ ), forward bending with vibrational stress $(\overline{\mathrm{x}}=2.08 \%, 0.0$ to $8.45 \%)$, lifting while twisting torso $(\overline{\mathrm{x}}=1.97 \%, 0.0$ to $5.99 \%)$, sitting $(\overline{\mathrm{x}}=$ $1.88 \%, 0.0$ to $5.13 \%$ ), standing while working with

Table 2. Activity/Body Position: Percentage of Occurrence Per Half-Shift for Excavation Crew

\begin{tabular}{|c|c|c|c|c|}
\hline \multicolumn{3}{|c|}{ Activity/Body Position } & Average (\%) & Range (\%) \\
\hline Lifting: & $\begin{array}{l}\text { light ob } \\
\text { heavy o } \\
\text { awkwar } \\
\text { while ty }\end{array}$ & $\begin{array}{l}\text { cts } \\
\text { ects } \\
\text { objects } \\
\text { sting }\end{array}$ & $\begin{array}{l}4.90 \\
2.74 \\
0.02 \\
1.97\end{array}$ & $\begin{array}{l}0.63-10.82 \\
0.31-6.76 \\
0.0-0.17 \\
0.0-5.99\end{array}$ \\
\hline \multicolumn{3}{|c|}{$\begin{aligned} \text { Carrying: } & \text { light objects } \\
& \text { heavy objects }\end{aligned}$} & $\begin{array}{l}3.50 \\
0.70\end{array}$ & $\begin{array}{l}0.99-9.14 \\
0.14-2.74\end{array}$ \\
\hline \multicolumn{2}{|c|}{ Pushing/Pulling: } & $\begin{array}{l}\text { dynamic } \\
\text { wheeled } \\
\text { nonwheeled } \\
\text { static }\end{array}$ & $\begin{array}{l}6.43 \\
0.10 \\
0.06 \\
0.02\end{array}$ & $\begin{array}{l}0.0-24.07 \\
0.0-0.82 \\
0.0-0.27 \\
0.0-0.16\end{array}$ \\
\hline \multicolumn{2}{|c|}{ Bending/leaning: } & $\begin{array}{l}\text { supporting } \\
\text { supported }\end{array}$ & $\begin{array}{l}0.31 \\
0.72\end{array}$ & $\begin{array}{l}0.0-2.74 \\
0.0-2.18\end{array}$ \\
\hline Bending: & \multicolumn{2}{|c|}{$\begin{array}{l}\text { forward } \\
\bar{c} \text { vibration } \\
\text { lateral }\end{array}$} & $\begin{array}{l}9.05 \\
2.07 \\
0.28 \\
0.68\end{array}$ & $\begin{array}{l}0.85-21.80 \\
0.0-8.45 \\
0.0-0.75 \\
0.0-1.99\end{array}$ \\
\hline \multicolumn{3}{|l|}{ Kneeling } & 0.34 & $0.0-2.56$ \\
\hline \multicolumn{3}{|l|}{ Squatting } & 0.74 & $0.0-4.01$ \\
\hline Reaching: & \multicolumn{2}{|c|}{$\begin{array}{l}\text { vertical } \\
\text { horizontal }\end{array}$} & $\begin{array}{l}0.27 \\
0.50\end{array}$ & $\begin{array}{l}0.0-0.99 \\
0.0-1.99\end{array}$ \\
\hline \multicolumn{3}{|l|}{ Twisting } & 0.07 & $0.0-0.54$ \\
\hline Standing: & \multicolumn{2}{|c|}{ working $\bar{c}$ hands } & 1.39 & $0.0-5.80$ \\
\hline \multicolumn{3}{|l|}{ Standing } & 18.38 & $0.0-36.63$ \\
\hline \multicolumn{3}{|l|}{ Sitting } & 1.88 & $0.0-5.13$ \\
\hline \multicolumn{3}{|c|}{ Driving/riding } & 26.49 & $8.58-93.08$ \\
\hline \multicolumn{3}{|c|}{ Backhoeing operation } & 8.88 & $0.0-71.07$ \\
\hline \multicolumn{3}{|c|}{ Walking } & .6 .00 & $0.63-10.90$ \\
\hline \multicolumn{3}{|c|}{ Climbing stairs: } & 0.27 & $0.0-0.81$ \\
\hline \multicolumn{3}{|c|}{ Throwing dirt: } & 1.20 & $0.0-4.09$ \\
\hline
\end{tabular}


hands ( $\overline{\mathrm{x}}=1.39 \%, 0.0$ to $5.80 \%)$, and throwing dirt with shovel $(\overline{\mathrm{x}}=1.20 \%, 0.0$ to $4.09 \%)$. The remainder of the observed activity/body positions individually account for less than $1 \%$ of the total average number of observations, and in aggregate account for $5.11 \%$ of the total average.

\section{Cleanup Crew}

Table 3 lists the average percentages and their ranges for each major activity/body position. Driving/ riding was the most common activity $(\overline{\mathrm{x}}=60.99 \%$, range 52.66 to $69.32 \%$ ). Walking was the second most common activity $(\overline{\mathrm{x}}=9.69 \%, 5.72$ to $13.66 \%)$ followed by sitting $(\bar{x}=5.65 \%, 3.85$ to $7.44 \%)$. Standing took fourth place ( $\overline{\mathrm{x}}=3.94 \%, 3.19$ to $4.69 \%)$ followed closely by forward bending $(\overline{\mathrm{x}}=3.46 \%, 2.06$ to $4.86 \%$ ). Carrying light objects was the sixth most common activity $(\bar{x}=3.37 \%, 1.13$ to $5.61 \%)$, followed in order by light lifting ( $\overline{\mathrm{x}}=2.92 \%, 2.35$ to $3.49 \%)$ and heavy lifting $(\bar{x}=1.02 \%, 0.91$ to $1.13 \%)$. The remainder of the observed activity/body positions individually account for less than $1 \%$ of the total average number of observations, and in aggregate account for $9.03 \%$ of the total average.

\section{Table 3. Activity/Body Position: Percentage of}

Occurrence Per Half-Shift for Cleanup Crew

\begin{tabular}{|c|c|c|c|c|}
\hline \multicolumn{3}{|c|}{ Activity/Body Position } & Average $(\%)$ & Range (\%) \\
\hline Lifting: & $\begin{array}{l}\text { light ol } \\
\text { heavy } \\
\text { awkwa } \\
\text { boxes }\end{array}$ & $\begin{array}{l}\text { jects } \\
\text { bjects } \\
\text { d objects }\end{array}$ & $\begin{array}{l}2.92 \\
1.02 \\
0.34 \\
0.99\end{array}$ & $\begin{array}{l}2.35-3.49 \\
0.91-1.13 \\
0.30-0.38 \\
0.0-1.97\end{array}$ \\
\hline Carrying: & $\begin{array}{l}\text { light ol } \\
\text { heavy } \\
\text { awkwa }\end{array}$ & $\begin{array}{l}\text { jects } \\
\text { bjects } \\
\text { d objects }\end{array}$ & $\begin{array}{l}3.37 \\
0.79 \\
0.12\end{array}$ & $\begin{array}{l}1.13-5.61 \\
0.66-0.91 \\
0.09-0.15\end{array}$ \\
\hline \multicolumn{3}{|c|}{ Throwing/Tossing item } & 0.24 & $0.0-0.47$ \\
\hline \multicolumn{2}{|c|}{ Pushing/Pulling: } & $\begin{array}{l}\text { dynamic } \\
\text { wheeled } \\
\text { nonwheeled } \\
\text { static }\end{array}$ & $\begin{array}{l}0.92 \\
0.24 \\
0.96 \\
0.33\end{array}$ & $\begin{array}{l}0.15-1.69 \\
0.0-0.47 \\
0.61-1.31 \\
0.0-0.66\end{array}$ \\
\hline \multicolumn{2}{|c|}{ Bending/leaning: } & supported & 0.24 & $0.0-0.47$ \\
\hline Bending: & \multicolumn{2}{|c|}{$\begin{array}{l}\text { forward } \\
\text { lateral }\end{array}$} & $\begin{array}{l}3.46 \\
0.08\end{array}$ & $\begin{array}{l}2.06-4.86 \\
0.0-0.15\end{array}$ \\
\hline \multicolumn{3}{|l|}{ Stooping } & 0.74 & $0.56-0.91$ \\
\hline \multicolumn{3}{|l|}{ Squatting } & 0.23 & $0.0-0.46$ \\
\hline Reaching: & \multicolumn{2}{|c|}{$\begin{array}{l}\text { vertical } \\
\text { horizontal }\end{array}$} & $\begin{array}{l}0.55 \\
0.60\end{array}$ & $\begin{array}{l}0.15-0.94 \\
0.28-0.91\end{array}$ \\
\hline \multicolumn{3}{|l|}{ Twisting } & 0.05 & $0.0-0.09$ \\
\hline Standing: & \multicolumn{2}{|c|}{ working $\mathrm{c}$ hands } & 0.81 & $0.56-1.06$ \\
\hline \multicolumn{3}{|l|}{ Standing } & 3.94 & $3.19-4.69$ \\
\hline \multicolumn{3}{|l|}{ Sitting } & 5.65 & $3.85-7.44$ \\
\hline \multicolumn{3}{|c|}{ Driving/riding } & 60.99 & $52.66-69.32$ \\
\hline \multicolumn{3}{|l|}{ Walking } & 9.69 & $5.72-13.66$ \\
\hline \multicolumn{2}{|c|}{ Climbing stairs: } & $\begin{array}{l}\text { \$ carrying } \\
\bar{c} \text { carrying }\end{array}$ & $\begin{array}{l}0.70 \\
0.10\end{array}$ & $\begin{array}{l}0.46-0.94 \\
0.0-0.19\end{array}$ \\
\hline
\end{tabular}




\section{Grounds Crew}

The average percentage and their range for each major activity/body position is listed in Table 4 . The most commonly observed activity was forward bending ( $\bar{x}=16.72 \%$, range 4.68 to $29.89 \%$ ), followed closely by standing while working with hands $(\overline{\mathrm{x}}=$ $16.04 \%, 1.54$ to $45.66 \%$ ). Walking was the third most common activity ( $\overline{\mathrm{x}}=10.51 \%, 6.44$ to $13.23 \%)$, and standing was fourth $(10.05 \%, 0.70$ to $15.56 \%)$. The fifth most common activity was driving/riding $(\overline{\mathbf{x}}=$ $8.99 \%, 0$ to $26.83 \%$ ), and dynamic pushing/pulling of wheeled objects was $\operatorname{sixth}(\overline{\mathrm{x}}=8.30 \%, 0$ to $25.58 \%)$.
Following these in order were: lifting light objects $(\overline{\mathrm{x}}=5.30 \%, 0$ to $16.36 \%)$, squatting $(\overline{\mathrm{x}}=4.16 \%, 0$ to $11.51 \%)$, dynamic pushing/pulling $(\overline{\mathrm{x}}=63.08 \%, 0$ to $7.15 \%$ ), dynamic pushing/pulling of nonwheeled objects $(\overline{\mathrm{x}}=2.15 \%, 0$ to $5.66 \%)$, stooping $(\overline{\mathrm{x}}=1.92 \%$, 0.10 to $6.32 \%)$, kneeling ( $\bar{x}=1.89 \%, 0$ to $3.40 \%$ ), and sitting $(\overline{\mathrm{x}}=1.84 \%, 0$ to $3.90 \%)$. The remainder of the recorded activity/body positions individually account for less than $1 \%$ of the total average number of observations, and in aggregate account for $3.14 \%$ of the total average.

\section{Table 4. Activity/Body Position: Percentage of Occurrence Per Half-Shift for Grounds Crew}

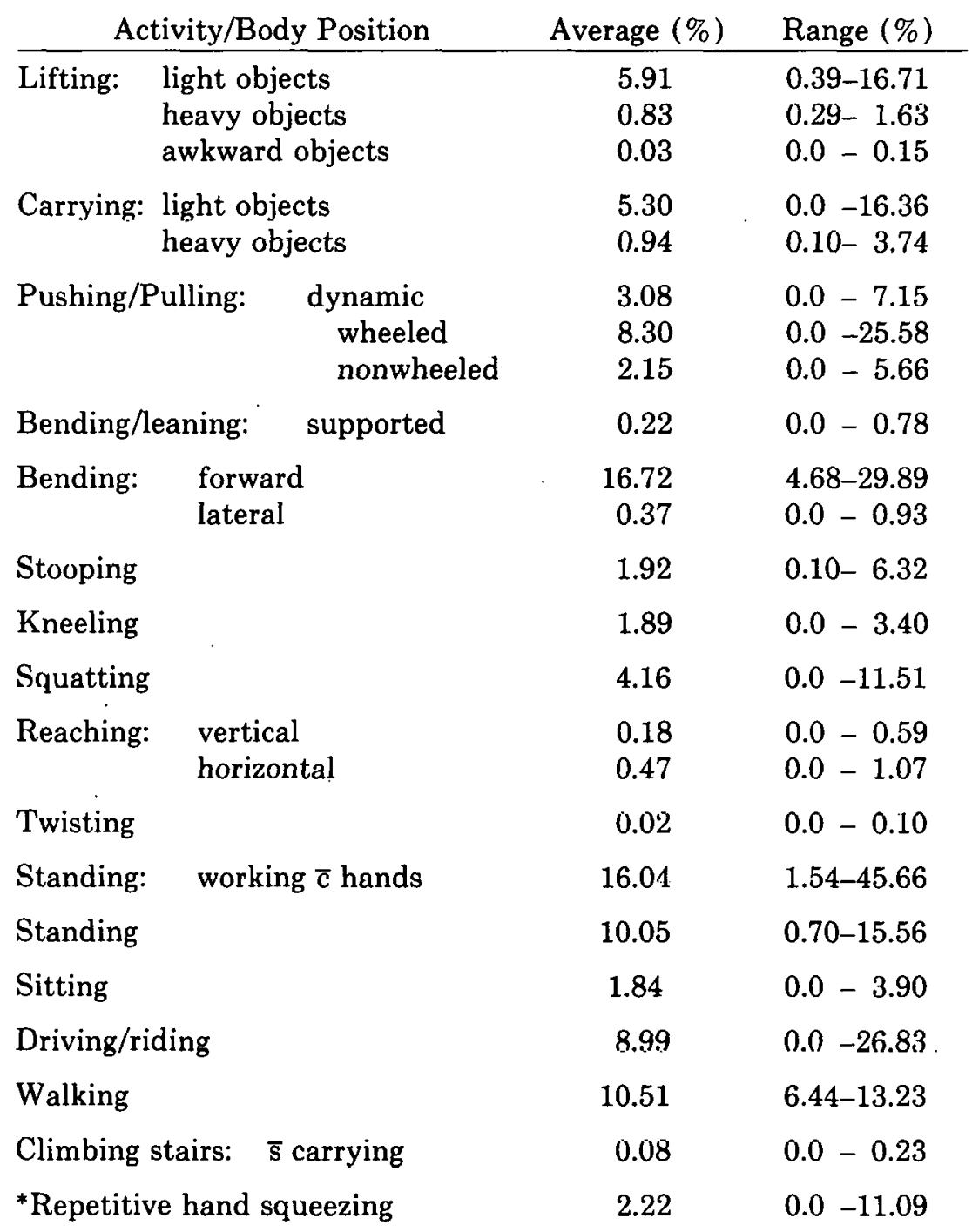

*Occurred during another major body position (forward bending). 


\section{Combined Data}

The average percentages and their ranges for all data combined for each major activity/body position are listed in Table 5. The most common activity for the combined data is driving/riding $(\bar{x}=27.42 \%$, range 0 to $93.08 \%$ ). Standing was the second most common activity $(\overline{\mathrm{x}}=14.11 \%, 0$ to $36.63 \%)$ and walking was third $(\overline{\mathrm{x}}=10.56 \%, 0.63$ to $23.20 \%)$. Forward bending was the fourth most common activity $(\overline{\mathrm{x}}=7.22 \%, 0.62$ to $29.89 \%)$. Sitting was fifth $(\overline{\mathrm{x}}=$ $4.62 \%, 0$ to $13.30 \%$ ), and standing while working with hands was sixth $(\bar{x}=4.17 \%, 0$ to $45.66 \%)$.

These were followed in order by: dynamic pushing/pulling of wheeled objects $(\overline{\mathrm{x}}=3.92 \%, 0$ to $25.58 \%)$, pushing/pulling dynamic $(\bar{x}=3.58 \%, 0$ to $24.07 \%)$, lifting light objects $(\bar{x}=3.32 \%, 0.23$ to $16 .(1 \%)$, carrying light objects $(\overline{\mathrm{x}}=3.03 \%, 0$ to $16.36 \%)$, other activities/body positions $(\bar{x}=3.01 \%$, 0 to $71.07 \%$ ), kneeling ( $\mathrm{x}=2.17 \%, 0$ to $37.28 \%$ ), lifting heavy objects $(\mathbb{x}=1.92 \%, 0.29$ to $6.76 \%)$, dynamic pushing/pulling nonwheeled objects $(\bar{x}=$ $1.92 \%, 0$ to $6.38 \%$ ), squatting ( $\bar{x}=1.60 \%, 0$ to $11.51 \%)$, carrying heavy objects $(\bar{x}=1.15 \%, 0.10$ to $3.74 \%)$, and lifting boxes ( $\bar{x}=1.09 \%, 0.0$ to $5.26 \%$ ). The remainder of the recorded activities/body positions individually account for less than $1 \%$ of the total average number of observations, and in aggregate account for $6.03 \%$ of the total average.

The total average for all types of lifting was $6.55 \%$ (range 0.68 to $17.41 \%$ ). The total carrying average was $4.84 \%$ (range 0.10 to $16.67 \%$ ), and the total pushing/ pulling average was $8.94 \%$ (range 9 to $25.89 \%$ ).

The weights and weight ranges of items most commonly lifted by the individual workers are listed in Table 6. The jackhammer most commonly used weighed $95 \mathrm{lb}$. The filled moving or loading boxes had an average weight of $>63 \mathrm{lb}$ with a range of 5 to $>100$ lb. Small empty bookshelves had an average weight of $62 \mathrm{lb}$ (range 56 to $68 \mathrm{lb}$ ), and empty desk organizers weighed $46 \mathrm{lb}$. Desk chairs had an average weight of 37 lb (range 30 to $40 \mathrm{lb}$ ), the dolly used to move desks weighed $36 \mathrm{lb}$, and wooden crates weighed $36 \mathrm{lb}$ with a range of 28 to $50 \mathrm{lb}$. The small porcelaiii writing boards weighed $35 \mathrm{lb}$, the small, less commonly used jackhammer weighed $33 \mathrm{lb}$, and the skids or pallets weighed $33 \mathrm{lb}$ with a range of 31 to $35 \mathrm{lb}$. Stools weighed $27 \mathrm{lb}$, the "safe dolly" weighed $23 \mathrm{lb}$, and the average weight of hand tools such as shovels, picks, digging rods, brooms, rakes, etc, was $4 \mathrm{lb}$ with a range of 3 to $19 \mathrm{lb}$. The temporary wooden barriers weigh 4 $\mathrm{lb}$ and empty cardboard boxes picked up as trash averaged $2 \mathrm{lb}$ with a range of 1 to $4 \mathrm{lb}$. 
Table 5. Activity/Body Position: Percentage of
Occurrence Per Half-Shift for Combined Data

\begin{tabular}{|c|c|c|c|c|}
\hline \multicolumn{3}{|c|}{ Activity/Body Position } & Average $(\%)$ & Range (\%) \\
\hline Lifting: & $\begin{array}{l}\text { light of } \\
\text { heavy } \\
\text { awkwar } \\
\text { boxes } \\
\text { lifting }\end{array}$ & $\begin{array}{l}\text { ojects } \\
\text { bjects } \\
\text { d objects } \\
\text { with twist }\end{array}$ & $\begin{array}{l}3.32 \\
1.92 \\
0.13 \\
1.09 \\
0.58\end{array}$ & $\begin{array}{l}0.23-16.71 \\
0.29-6.76 \\
0.0-0.70 \\
0.0-4.26 \\
0.0-5.99\end{array}$ \\
\hline \multicolumn{3}{|c|}{$\begin{aligned} \text { Carrying: } & \text { light objects } \\
& \text { heavy objects } \\
& \text { awkward objects } \\
& \text { boxes }\end{aligned}$} & $\begin{array}{l}3.03 \\
1.15 \\
0.18 \\
0.48\end{array}$ & $\begin{array}{l}0.0-16.36 \\
0.10-3.74 \\
0.0-2.02 \\
0.0-3.65\end{array}$ \\
\hline \multicolumn{2}{|c|}{ Pushing/Pulling: } & $\begin{array}{l}\text { dynamic } \\
\text { wheeled } \\
\text { nonwheeled } \\
\text { static }\end{array}$ & $\begin{array}{l}3.58 \\
3.92 \\
1.92 \\
0.27\end{array}$ & $\begin{array}{l}0.0-24.07 \\
0.0-25.58 \\
0.0-6.38 \\
0.0-2.32\end{array}$ \\
\hline \multicolumn{3}{|c|}{$\begin{aligned} & \text { Bending/leaning: } \text { supporting } \\
& \text { supported }\end{aligned}$} & $\begin{array}{l}0.51 \\
0.96\end{array}$ & $\begin{array}{l}0.0-2.74 \\
0.0-5.26\end{array}$ \\
\hline Bending: & \multicolumn{2}{|c|}{$\begin{array}{l}\text { forward } \\
\quad \bar{c} \text { vibration } \\
\text { lateral }\end{array}$} & $\begin{array}{l}7.22 \\
0.80 \\
0.30\end{array}$ & $\begin{array}{l}0.62-29.89 \\
0.0-8.45 \\
0.0-2.80\end{array}$ \\
\hline \multicolumn{3}{|l|}{ Stooping } & 0.84 & $0.0-6.32$ \\
\hline \multicolumn{3}{|l|}{ Kneeling } & 2.17 & $0.0-37.28$ \\
\hline \multicolumn{3}{|l|}{ Squatting } & 1.60 & $0.0-11.51$ \\
\hline Reaching: & \multicolumn{2}{|c|}{$\begin{array}{l}\text { vertical } \\
\text { horizontal }\end{array}$} & $\begin{array}{l}0.43 \\
0.47\end{array}$ & $\begin{array}{l}0.0-2.55 \\
0.0-1.99\end{array}$ \\
\hline \multicolumn{3}{|l|}{ Twisting } & 0.09 & $0.0-0.55$ \\
\hline \multicolumn{3}{|l|}{ Standing: } & 4.17 & $0.0-45.66$ \\
\hline \multicolumn{3}{|l|}{ Standing } & 14.11 & $0.0-36.63$ \\
\hline \multicolumn{3}{|l|}{ Sitting } & 4.62 & $0.0-13.30$ \\
\hline \multicolumn{3}{|c|}{ Driving/riding } & 27.42 & $0.0-93.08$ \\
\hline \multicolumn{3}{|l|}{ Walking } & 10.56 & $0.63-23.20$ \\
\hline \multicolumn{3}{|c|}{ Climbing stairs: } & $\begin{array}{l}0.48 \\
0.09\end{array}$ & $\begin{array}{l}0.0-1.86 \\
0.0-1.33\end{array}$ \\
\hline \multicolumn{3}{|l|}{ Other } & 3.01 & $0.0-71.07$ \\
\hline \multicolumn{3}{|c|}{ Total Lifting } & 6.55 & $0.68-17.41$ \\
\hline \multicolumn{3}{|c|}{ 'T'otal Carrying } & 4.84 & $0.10-16.67$ \\
\hline \multicolumn{3}{|c|}{ Total Pushing/Pulling } & 8.94 & $0.0-25.89$ \\
\hline
\end{tabular}




\section{Table 6. Items Most Often Lifted by Single Person on Telecon Crew}

\begin{tabular}{lcc}
\multicolumn{1}{c}{ Item } & $\begin{array}{c}\text { Average Weight/ } \\
\text { Unit (lb) }\end{array}$ & Range (lb) \\
\hline Jackhammer (large) & 95 & 95 \\
Boxes (filled loading boxes) & $>63$ & $5->100$ \\
Small bookshelves (empty) & 62 & $56-68$ \\
Desk organizers (empty) & 46 & 46 \\
Desk chairs & 37 & $30-40$ \\
Desk dolly & 36 & 36 \\
Crates (wooden boxes) & 36 & $28-50$ \\
Porcelain writing boards (small) & 35 & 35 \\
Jackhammer (small) & 33 & 33 \\
Sltdo (Pallutu) & 33 & $31-35$ \\
Stools & 27 & 27 \\
"Safe dolly" & 23 & 23 \\
Hand tools & 9 & $3-19$ \\
Temporary wooden barriers & 4 & 4 \\
Empty boxes (cardboard) & 2 & $1-4$ \\
\hline
\end{tabular}

\section{Discussion}

The laborers in this study all had the same section supervisor. Within this section the laborers were divided among four work areas, with most workers being rotated through all four areas. Rotational changes occur on a monthly basis, with two nonrotating laborers. The four work areas are Telecon (two crews of three members), Excavating (one crew of two members), Cleanup (one crew of two members), and Landscaping and Grounds Maintenance (variable crews with variable members). The physical and ergonomic aspects of the most common activities/body positions of selected nonskilled heavy laborers are given in Table 7 .

Each Telecon Crew, the Excavating Crew, and the Grounds Crew are headed by a lead person (Grade 6 or 7). The remainder of the laborers are Grade 3 or 4 . The laborers work a regular day shift.

Although there may be a great deal of overlap, the primary responsibilities of each group are as follows. The Telecon Crew is responsible for the movement and transportation of furniture, nonsensitive equipment, and boxes of miscellaneous items between buildings and/or offices in response to requests phoned in to Telecon. The Excavating Crew is responsible for any type of excavation, placement of nonfence barriers, installation and repair of security fences, posting of signs, and the operation of heavy equipment such as the backhoe and tractor. The Cleanup Crew is responsible for hazardous chemical pickup, emptying outside trash cans, removal of large trash items such as crates, boxes, and wooden pallets (skids), and the proper disposal of all items. The Grounds Crew is responsible for maintaining all landscapped areas at the Laboratories; this includes watering, pruning, digging, planting, weeding, lawn maintenance, pesticide spraying, spreading of gravel, etc. The Grounds Crew also is responsible for maintaining the plant nursery, and chemical weed control in nonlandscapped areas. Some grounds keepers work individually, others as members of a team. All Labor Crews, with the exception of the Telecon Crew, are required to pick up and remove litter.

The jul requlrements of the laburers are exlremely variable. They are significantly modified by the season of the year, the weather, Laboratory activities and priorities, and acts of God. Therefore, the interpretation of the data and their use in making extrapulations are limited by the conditions under which they were obtained; i.e., during the spring with mild weather, with no major Laboratory changes or special assignments requiring overtime, and no unusual occurrences.

A deviation from the previously used methodolo$\mathrm{gy}^{1}$ was required in studying the laborers. The labor job is very nonroutine, and each major task incorporates smaller subtasks that need to be analysed. During the performance of their job, a Labor Crew could initiate and complete a subtask or a specific component of a major task in less time than needed by. the 
investigator to read and record elapsed time for the immediately previous task. A 15-s interobservational survey, as described in the methodology section, was therefore instituted to provide a more accurate measurement procedure.

The use of a regular periodic observational survey does not yield certain types of information that had been obtained using the continuous measurement technique, such as the distance walked, the average amount of time necessary to perform routine repetitive tasks, the number of items lifted or carried, etc. Given the nonroutine nature of the job and the more exact measurements related to body positions by the technique employed, the above was not believed to be detrimental to the project.

Body positions and tasks begun and completed within a 15-s interobservational period were not recorded, and in the analysis of the data those body positions or tasks observed at the termination of each 15 -s interval are assumed to occur for the full $15 \mathrm{~s}$. These two inherent errors within the measurement technique become very small as the number of observations become very large. The number of observations used in this analysis exceeded 16,000 .

\section{Table 7. Physical and Ergonomic Aspects of the Most Common Activities/Body Positions of Selected Nonskilled Heavy Laborers}

\begin{tabular}{ll}
$\begin{array}{l}\text { Activity/Body } \\
\text { Position }\end{array}$ & \multicolumn{1}{c}{ Physical and Ergonomic Aspects } \\
\hline Lifting & $\begin{array}{l}\text { Lifting distances for these nonroutine type } \\
\text { tasks encompasses the entire lifting spectrum, } \\
\text { with the majority of lifts occurring between } \\
\text { midcalf and shoulder level. Knees and/or back } \\
\text { may be straight or bent. Loading of the spine } \\
\text { may be unilateral or bilateral. Often, twisting } \\
\text { occurred during the lift. }\end{array}$
\end{tabular}

Light objects Estimated or measured at $25 \mathrm{lb}$ or less.

Heavy objects Estimated or measured at greater than $25 \mathrm{lb}$.

Awkward objects When the difficulty of lifting due to the size or dimension of the object was more significant than the weight of the object.

\section{Boxes}

Carrying

Light objects $\leq 25 \mathrm{lb}$ measured or estimated.

Heavy Objects: $>25$ lb estimated or measured.

Awkward objects When the difficulty of carrying is due to the size or proportions of the object rather than Its welght.

Boxes Due to the difficulty in visual estimation of the weight of a loaded box.

Pushing/Pulling

Dynamic wheeled
Task Examples in Which Activity/ Body Position is a Component
Light lifting, digging, pulling weeds, using pick, digging postholes, picking up trash, mixing cement

Heavy lifting, digging, pulling weeds, using jackhammer, mixing cement

Lifting, picking up trash

Lifting boxes, moving offices

Carrying items

Edging lawn, carrying tools

Furniture, equipment, etc

Picking up trash

Moving offices

Moving wheeled furniture, pushing of cart; pushing lawn mower 
Table 7. (Cont)

Activily/Budy Position

Dynamic nonwheeled

Dynamic

Static

Bending/leaning

Supported

Supporting

Bending

Forward

Lateral

Stooping

Squatting

Kneeling

Reaching
Physical and Ergonomic Aspects

Pushing or pulling of any large object in contact with the walking/working surface which does not have wheels or is not placed on a wheeled platform.

Any dynamic pushing/pulling action, in any direction, not included above. Foreward bending with a bent back is a common occurrence.

Any statıc pushing/pülling action in any direction.

Body in a forward or lateral bending position and supported or partially supported by another object.

Body in a forward or lateral bending position supporting another object.

Forward bending from waist with knees straight or slightly flexed without actively lifting or carrying nhjest.

Lateral bending from waist without actively lifting or carrying object.

A forward leaning from the waist (less body angleatiưn than with forward bending), with head lowered.

Back may be straight or bent. Both knees are maximally bent. Body supported by feet with buttock resting on heels. Normally is an optional position and occurs in place of forward bending.

Body supported on one or both knees. Back may be straight or bent. Normally is an optional position and occurrs in place of forward bending.

Categorized according to major angular component.
Taols Examploo in Which Activity/ Body Position is a Component

Moving furniture, equipment, boxes; pulling long water hose

Opening/closing door, pushing small items out of path, raking, sweeping, scooping with shovel, pulling short water hose, starting lawn mower, hoeing, using pick, mixing cement

Furnilure, equipment, ele

Lowering tailgate, searching for small items, orienting, reading, talking on phone, resting ( $<5 \mathrm{~min}$ )

Supporting/balancing equipment or furniture

Searching for item, reading, orienting, pulling weeds, picking up trash, digging, raking, hoeing, edging lawn, hoeing. watering plants, using jackhammer, using pick, digging postholes, mixing cement

Digging, searching for item, picking up small objects

Dialing telephone, talking on phone, reading, looking for omall itomo, hooing, watering plants, digging

Assembling furniture or equipment, resting, $(<5 \mathrm{~min})$, orienting, searching for items, marking areas, digging, watering plants, pulling weeds

Assembling furniture or equipment; resting ( $<5 \mathrm{~min}$ ), obtaining tools, searching for small items, reading, orienting, watering plants, digging, pulling weeds

Assembling items, obtaining items 
Table 7. (Cont)

\begin{tabular}{|c|c|c|}
\hline $\begin{array}{l}\text { Activity/Body } \\
\text { Position }\end{array}$ & Physical and Ergonomic Aspects & $\begin{array}{l}\text { Task Examples in Which Activity/ } \\
\text { Body Position is a Component }\end{array}$ \\
\hline Vertical & $\begin{array}{l}0^{\circ} \text { to } 45^{\circ} \text { and } 135^{\circ} \text { to } 180^{\circ} \text { from anatomical } \\
\text { position. }\end{array}$ & Using pick \\
\hline Horizontal & $>45^{\circ}$ to $135^{\circ}$ from anatomical position. & Hoeing, using pick, digging \\
\hline Twisting & Axial rotation of trunk in relation to pelvis. & Digging, driving tractor \\
\hline Without lifting & With or without load. & $\begin{array}{l}\text { Carrying, digging, picking up trash } \\
\text { driving tractor }\end{array}$ \\
\hline With lifting & During a lift. & Lifting, digging, picking up trash \\
\hline \multicolumn{3}{|l|}{ Standing } \\
\hline Standing & Self-explanatory. & $\begin{array}{l}\text { Guiding truck or forklift, waiting, } \\
\text { watching, receiving instructions, orient- } \\
\text { ing, riding elevator, talking, watering } \\
\text { plants, digging }\end{array}$ \\
\hline $\begin{array}{l}\text { Working } \bar{c} \\
\text { hands }\end{array}$ & Light handwork while standing. & $\begin{array}{l}\text { Assembling equipment, posting, wiring, } \\
\text { tying rope, watering plants, using jack- } \\
\text { hammer, digging }\end{array}$ \\
\hline Sitting & $\begin{array}{l}\text { Not driving, riding in or operating motorized } \\
\text { equipment. Often is an optional position- } \\
\text { occurring in place of another position. }\end{array}$ & $\begin{array}{l}\text { Receiving instructions, resting } \\
\text { ( }<5 \text { min), orienting, reading, talking, } \\
\text { telephoning, watering plants, digging, } \\
\text { pulling weeds }\end{array}$ \\
\hline Driving/Riding & $\begin{array}{l}\text { Driving or riding in motorized vehicle. May } \\
\text { involve twisting of torso. }\end{array}$ & $\begin{array}{l}\text { Using truck, lawn mower, forklift, } \\
\text { backhoe, tractor }\end{array}$ \\
\hline $\begin{array}{l}\text { Operating } \\
\text { Backhoe }\end{array}$ & Operating backhoe but not driving. & Digging/excavating \\
\hline Walking & Self-explanatory & $\begin{array}{l}\text { In transition/preparing, orientating, } \\
\text { waiting }(<5 \mathrm{~min}) \text {, hoeing, pulling weeds }\end{array}$ \\
\hline \multicolumn{3}{|l|}{ Climbing Stairs } \\
\hline$\overline{\mathrm{s}}$ carrying & Not carrying items. & In transition/preparing \\
\hline$\overline{\mathrm{c}}$ carrying & Carrying items. & Moving furniture, equipment \\
\hline
\end{tabular}

Except for the occasional independent groundskeeper, all the laborers in the study group worked as part of a team. This is necessary due to the weight of many of the items lifted being well over $200 \mathrm{lb}$, the number of items manually handled, and the difficulty in accomplishing many of the tasks (Figures 1 through 3 ). This situation offers little potential for accommodations of persons with physical limitations.
The majority of laborers in the study group rotate through each job area. Therefore, the physical restrictions or functional limitations which can be accommodated is limited by the most physically stressful of the four jobs. The most physically stressful jobs on the average are Telecon and excavating, although the spreading of gravel on the grounds job also is very demanding. Since stooping, kneeling, squatting, twisting, and sitting (not driving/riding) are often optional body positions, mild to moderate restrictions or physical limitations in these areas can be accommodated on the nonskilled heavy labor positions studied. 


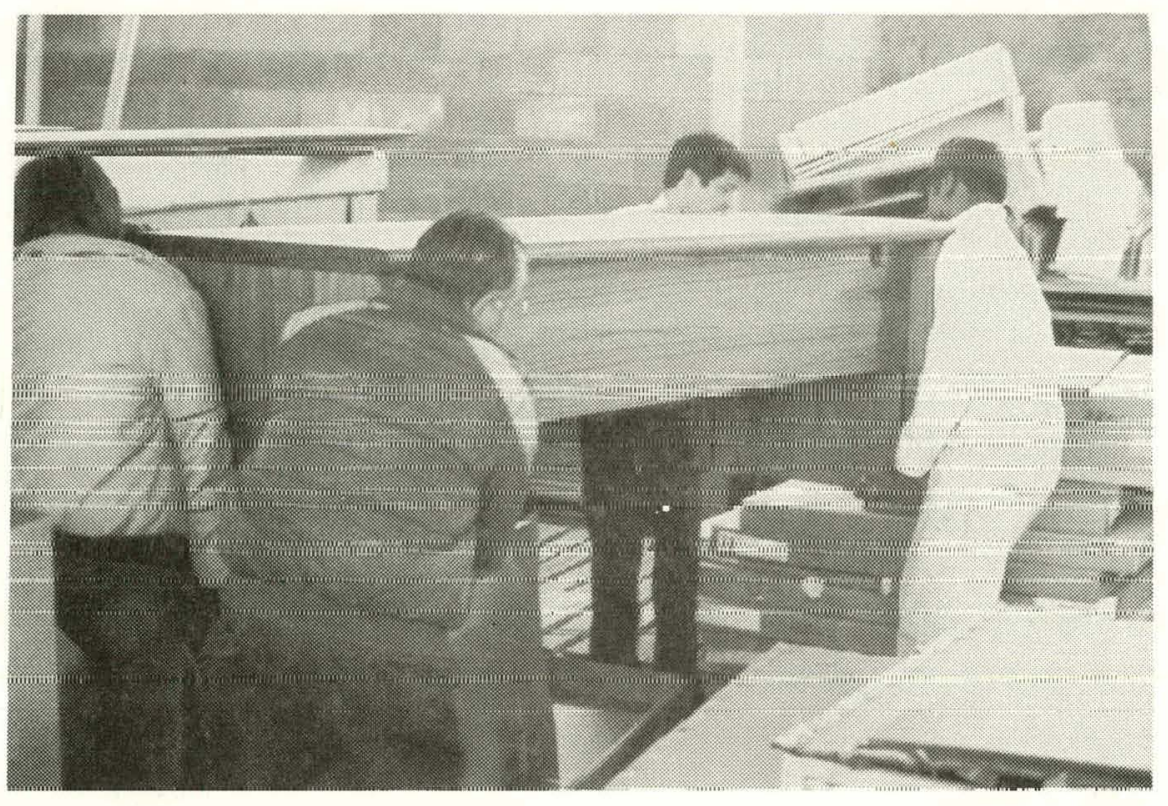

Figure 1. Laborers Lifting Heavy Object. Many of the items manually lifted are very heavy and/or are to be removed from or placed in tight quarters.

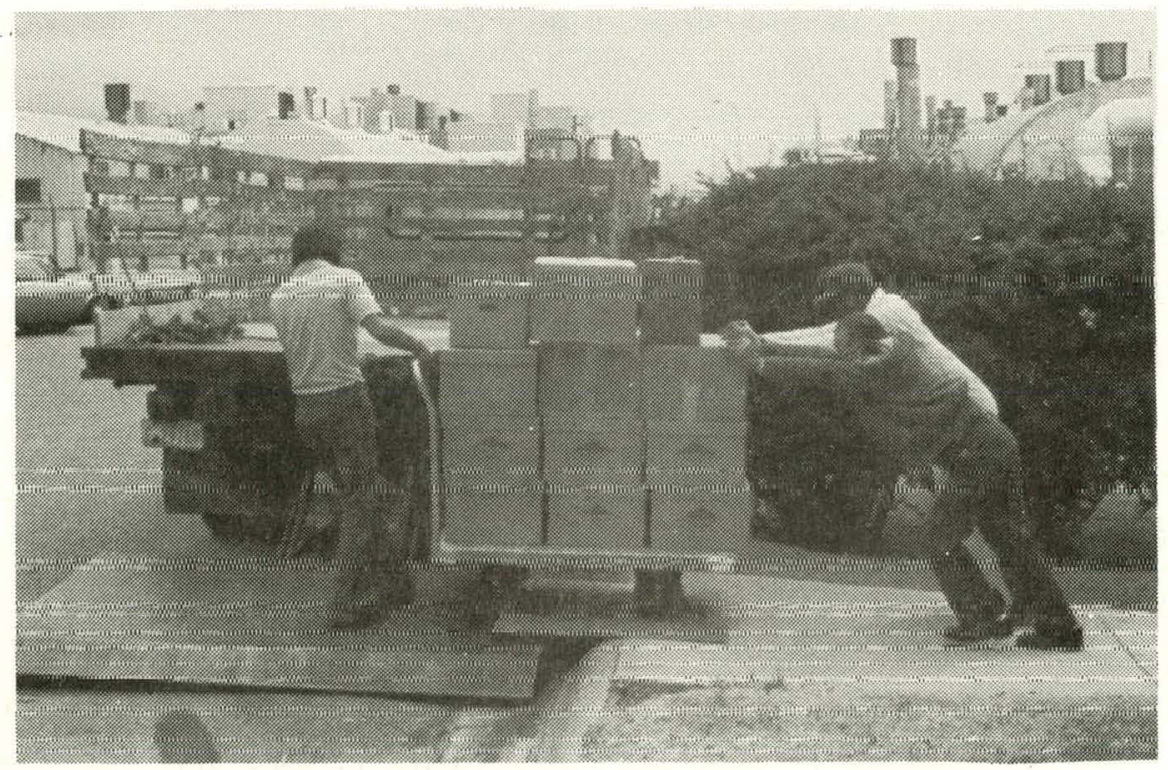

Figure 2. Laborers Pulling/Pushing Heavy Load. Many items are manually handled each day, and the difficulty of task performance is beyond what an independent worker would be expected to accomplish. 


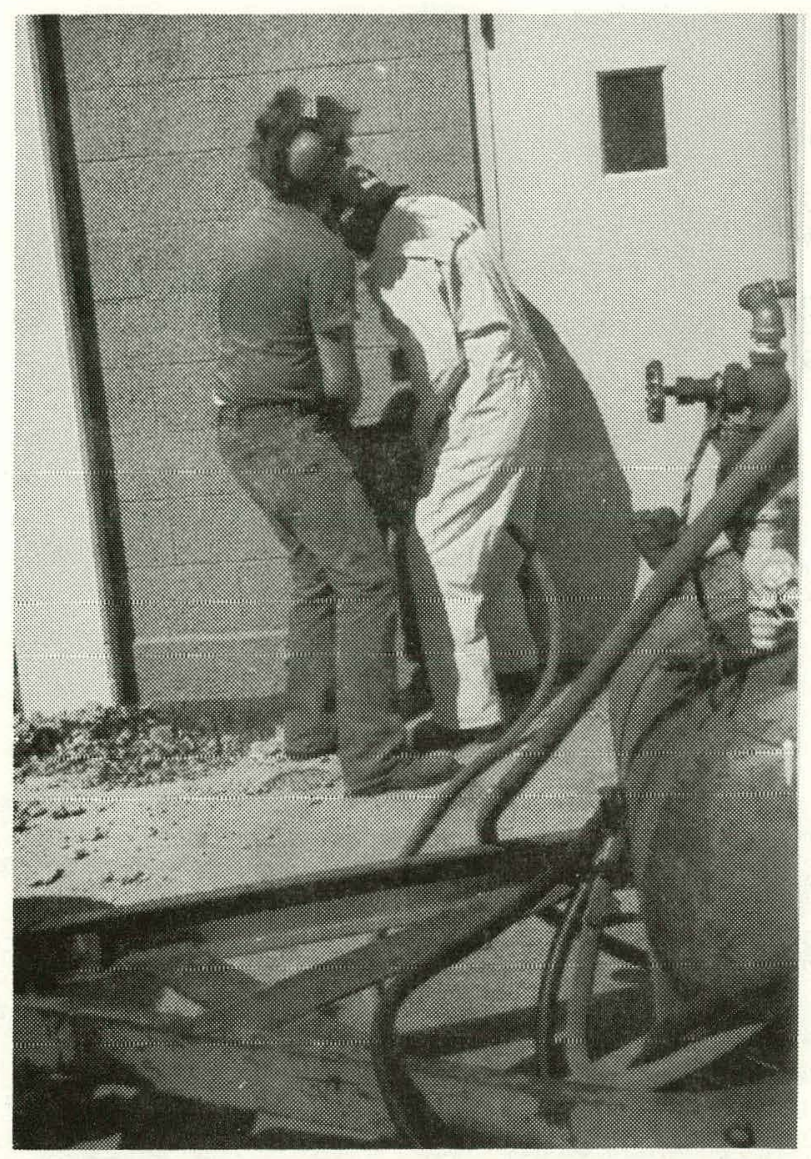

Figure 3. Iahorers I Ising Inrkhammer. Often the difficulty of a task cannot be measured simply by the weight of an item to be lifted.

The Telecon and excavating jobs have no potenlial for persuns with restrictions on lifting, carrving, pushing, pulling, bending, repetitive bending, reaching, standing, or walking. Even though one person had a weight restriction, he was observed lifting items beyond his medical limit, thereby placing himself at risk of injury. His attempts to work within his medical limitation places an increased burden on his teammales and thereby increases their risk of injury.

The cleanup job is less physically demanding, and a person with a 50-lb lifting restriction could be accommodated if the individual did not have any restrictions or functional limitations on pushing, pulling, bending, repetitive bending, or reaching. Minor restrictions on standing, walking, and driving could be accommodated in this job.

The Grounds Crew has the highest potential for accommodating physically restricted persons due to the larger number of workers in the crew and the many diffcrent responsibilities of the group. Accommodation of persons with a temporary restriction that would inhibit regular rotation through the other groups is feasible and desirable. Accommodation of a very small number of persons with permanent restrictions on lifting (20 lb or greater), carrying, pushing/ pulling, and reaching also is possible but less desirable and only if that person is a permanent member of the Grounds Crew and does not rotate through the other work groups. Permanent repetitive bending, reaching, standing, and walking restrictions cannot be accommodated.

The work performed by this study group of nonskilled heavy laborers has been classified previously as a heavy labor task. ${ }^{1}$ For the "average" laborer in this study, there is a significant potential for an acute strain of a healthy back and an even greater potential for an acute exacerbation of back pain from a degenerated disc or other structural defect.

Although the frequency of activity and the absolute time spent in any high-risk activity is low to moderate, the risk of injury occurs mainly in the Telecon and excavating jobs as well as in the grounds task of spreading gravel. Much of the risk of musculoskeletal injury is inherent in the job, although poor work habits, such as twisting the torso during a lift (Figure 4), improper lifting technique (Figure 5), and attempts to handle weights beyond their capabilities, greatly increase these risks.

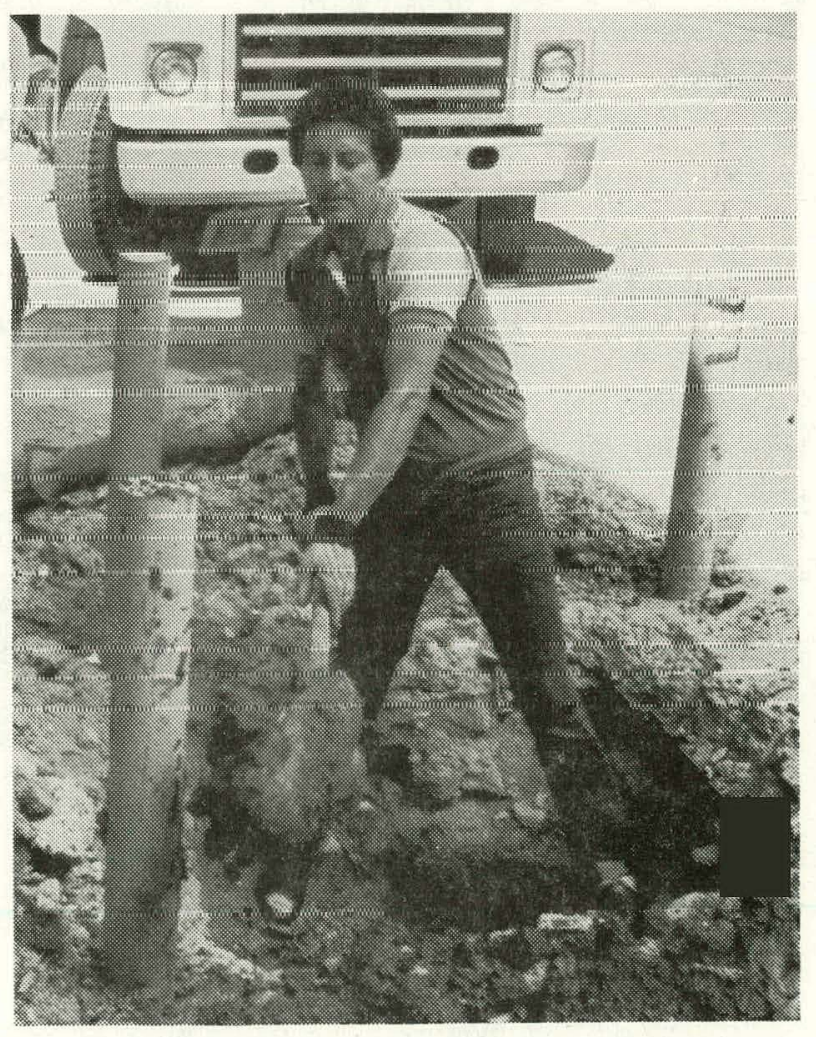

Figure 4. Twisting of Torso. Twisting of the torso during a lift is dangerous no matter what is being lifted. 


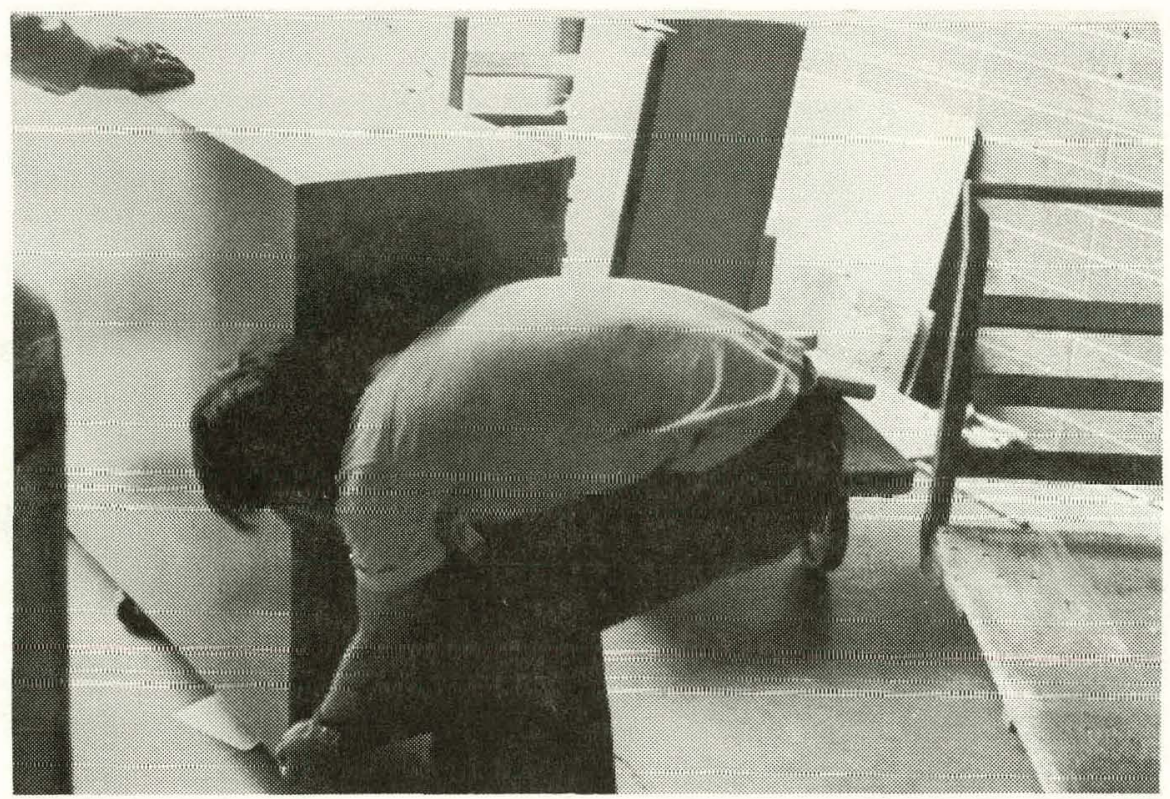

Figure 5. Improper Lifting Technique

The use of preemployment/pretransfer strength testing has been recommended in a previous report ${ }^{1}$ and also is recommended in this report. Any person who repeatedly lifts beyond his/her physical capability is increasing the risk of injury. ${ }^{2}$ Those persons who cannot demonstrate strengths equal to or exceeding the strength required to perform the job have a threefold increase in back pain incidence alone. ${ }^{3}$ Other musculoskeletal injuries also will increase at the same time. Most experts agree on the potential benefits of strength testing in industry, but the experinemlal difficulty of obtaining statistical proof of its efficiency has not been established. Until this is forthcoming, there exists a legal vulnerability concerning its use. Despite this risk in using industrial strength testing, a recent court decision ruled in favor of a plaintiff in a civil discrimination suit partly because the defendant company "did not test (the plaintiff's) strength or reach in any way." 4

There are several situations which contribute to the musculoskeletal stress, especially for the Telecon workers. The Laboratories' use of carpet and/or rugs in areas where equipment and/or furniture must be moved greatly increases the physical effort required. Although we do not suggest that all carpeting be eliminated, use of carpet in high traffic areas such as hallways, entry ways, and aisleways in larger offices should be minimized.

The occasional nonremovable guard rails on stair platforms at the elevated entrance to some buildings increases musculoskeletal stress on the workers while they are moving furniture and equipment since the equipment/furniture must be lifted over the nonremovable rail. Mobile offices (MOs) are often parked in such a way that the furniture truck cannot back up to the entrance platform, therefore requiring that many heavy items be lifted and carried rather than pushed.

Moving (or loadıng) boxes have typically been 24 $\mathrm{x} 16 \times 12$ in. or $16 \times 16 \times 16$ in. and have been too large and bulky to be manually handled safely. These boxes, when packed with office materials for a move, may exceed the maximum pormissible lift weight limit for a single person. The boxes are also bulky and therefore are difficult to lift and manually transport without inducing a significant stress on the vertebral column. Other additional risks associated with these loading boxes are the potential of packing them in an unsymmetrical manner and the possibility of a load shifting while the box is being carried.

'The use of short-handled hand tools such as shovels, brooms, ctc, requires increased forward bending by the worker, and therefore increases the duration of high intervertebral pressure which may increase the risk of spinal degeneration and back pain. Using short-handled tools in most cases also increase the metabolic energy required to perform the job and contributes to fatigue.

Failure of the employee requesting a furniture or equipment move to empty his/her desks, bookshelves, cabinets, etc, and overloading the loading boxes greatly increase the weight the laborer may lift and carry. 


\section{Conclusions and Recommendations}

Analysis of the data from a select group of nonskilled heavy laborers suggests that there is very little potential for the accommodation of permanently physically restricted or functionally limited personnel if they are to be rotated through the work groups. The types of restrictions or limitations which can be accommodated is limited by the physical demands of the Telecon and the excavating jobs. Accommodation potential is greater in the Cleanup Crew and Grounds Crew for temporary restrictions and/or for permanently restricted or physically limited personnel who will not rotate through the more demanding jobs.

Specific recommendations resulting from this study are given below.

\section{Physically Restricted/ Functionally Limited Employees}

Preemployment/pretransfer strength testing should be considered for all employees. Any person, whether physically restricted or not, who repeatedly lifts beyond his/her physical capability is predisposed to injury. Therefore, any person who is unable to meet the minimum requirements set for the nonskilled labor job on a preemployment/pretransfer strength test should be considered to have a functional limitation for this job. The strength testing should be performed prior to the assignment of any employee or potential employee to the nonskilled heavy labor group.

Persons with single, mild-to-moderate restrictions/limitations on lateral bending, squatting, twisting, or sitting may be accommodated on any work group by modifying work habits.

Most mild-to-moderate restrictions involving vision, hearing, dermatological problems, and environmental conditions may be accommodated.

Rotating laborers with restrictions/limitations on lifting, carrying, pushing, pulling, bending, repetitive bending, reaching, standing, or walking cannot be accommodated due to the resulting increased risk of injury to the accommodated employee and his teammates.

Persons with a temporary restriction/functional limitation and/or persons who will not rotate through the Telecon and excavating jobs may be accommodated as follows:
- A single person with a 50-lb weight lifting restriction/functional limitation may be accommodated on the Cleanup Crew if the person has no other related restriction or physical limitation.

- A very small number of persons with a 20-1b restriction on lifting/pulling/pushing, or mildto-moderate restrictions on standing, walking, or reaching may be accommodated on the Grounds Crew.

Accommodation of employees with physical restrictions affecting the employee's ability to perform the laborers' tasks should be limited to work teams.

The restricted/functionally limited employees should be greatly outnumbered on the same work team by employees with no functional limitation or physical restriction of the same or similar type.

Each accommodation should be considered on an individual basis by the Medical Department and line supervision based on the data in this report, the present number of physically restricted and functionally limited personnel, and any significant changes that may have subsequently occurred in the job.

\section{Training}

A program in materials handling and supervisory responsibility should be developed specifically for the hazards encountered in the job and instituted at SNL as an in-hours course. The supervisor, lead men, and all nonskilled heavy labor employees should be trained.

\section{Plant Modification}

The following plant modifications are suggested:

- Minimize the use of carpeting in areas of high traffic through which furniture and equipment are often moved.

- Whenever possible, provide removable hand/ guard rails on narrow outside stairs and elevated entrances to the first floor entrance to buildings.

- Park MOs far enough apart to permit furniture trucks to back up to the platform at the door opening.

- Use smaller moving boxes $(12 \times 15 \times 10 \text { in. })^{5}$

- Supply workers with long-handled hand tools; allow optional use of the short-handled hand tools.

- Supply all large motorized vehicles with a mechanical backup alarm. 


\section{Administrative Changes} ed:

The following administrative changes are suggest-

- Personnel whose furniture is being moved must remove all items from desks, bookshelves, cabinets, etc, before the move occurs.

- Personnel packing and loading/moving boxes must not overload boxes.

- Handtools must be properly maintained.

\section{References}

${ }^{1}$ L. L. Young and Paul B. Mossman, Accommodation Project For Physically Restricted Personnel. Phase 1: JobBased Criteria, SAND82-1023, (Albuquerque, NM: Sandia National Laboratories, May 1982).
${ }^{2}$ Work Practices Guide for Manual Lifting, NIOSH Technical Report No. 81-122, Chapter 2, US Department of Health and Human Services, Hublic Health Service, Centers for Disease Control, National Institute for Occupational Safety and Health, Division of Biomedical and Behavioral Science, Cincinnati, OH, March, 1981.

${ }^{3}$ D. B. Chaffin and K. S. Park, "A Longitudinal Study of Low Back Pain as Associated with Occupational Lifting Factors," Am Ind Hyg Assoc J 34:513-525, 1973.

${ }^{4}$ American Motors Corp. vs Labor and Industry Review Commission; Wisconsin Circuit Court, Dane County, No. 81-CV-1785, January 13, 1982.

${ }^{5}$ Paul B. Mossman, MD, Internal Memo to R. W. Hewes, "Large Loading Boxes May Increase Risk of Back Injuries". (Albuquerque, NM: Sandia National Laboratories, Ocluber 5, 1981. 


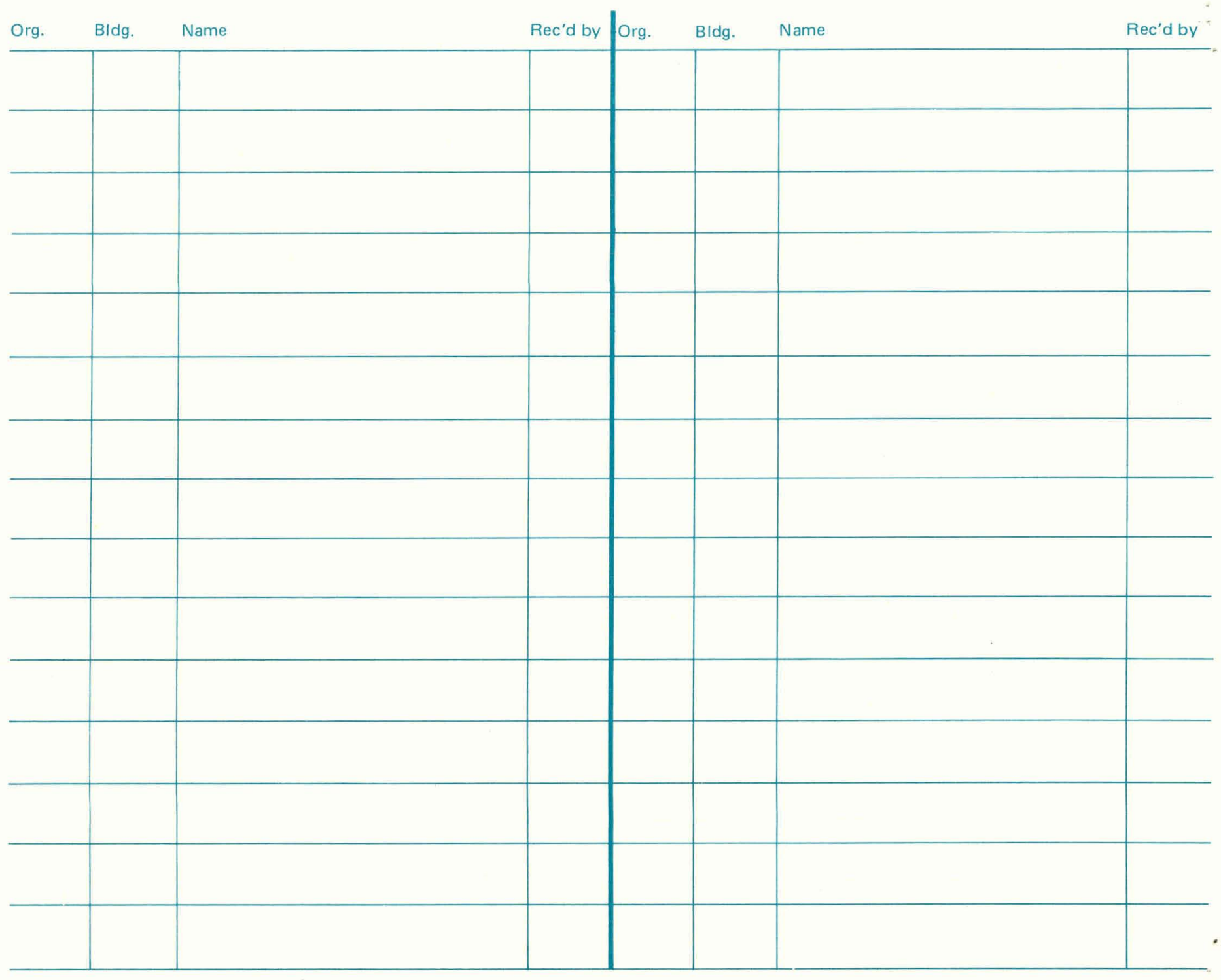

Sandia National Laboratories 